\title{
PENGARUH PERGANTIAN MANAJEMEN, KESULITAN KEUANGAN, FEE AUDIT, OPINI AKUNTAN DAN UKURAN KAP TERHADAP AUDIT CHANGES
}

\author{
Reni Yendrawati \\ Fakultas Ekonomi Universitas Islam Indonesia
}

\begin{abstract}
The number of public accountant firms increasing may result in commpetition between public accountant firms. In such condition, a corporation may change the auditor. The purpose of this research is to know whether the change of management, financial distress, audit fee, accountant opinion and public accountant firm's size may influence limited corporations in Indonesia to change auditors. The data being used is form manufacturing company which is listed in Indonesia Capital Market in 2007 - 2010 periods. The data is analyzed with logistic regression. This research result in audit fee and public accountant firm's size as variables influencing auditor changes of accountant opinion, financial distress and change of management as variables not influencing auditor changes .
\end{abstract}

Keywords: auditor changes, change of management, financial distress, audit fee and accountant opinion

\section{PENDAHULUAN}

KAP merupakan suatu bentuk organisasi akuntan publik yang telah memperoleh izin dari pemerintah sesuai dengan peraturan perundang-undangan yang bergerak dibidang pemberian jasa profesional dalam praktek akuntan publik. Kantor akuntan publik ini memberikan jasa kepada perusahaan untuk mengaudit laporan keuangan suatu perusahaan (Mulyadi, 2002). Meningkatnya kebutuhan jasa audit berpengaruh terhadap perkembangan profesi akuntansi publik di Indonesia. Bertambahnya jumlah kantor akuntan publik (KAP) yang beroperasi dapat menimbulkan persaingan antara KAP yang satu dengan yang lainnya, sehingga memungkinkan perusahaan untuk berpindah dari satu KAP ke KAP yang lain. Timbul dan berkembangnya profesi akuntan publik sangat dipengaruhi perkembangan perusahaan pada umumnya. Semakin banyak perusahaan publik, semakin banyak pula jasa akuntan publik yang dibutuhkan, oleh karena itu KAP saling bersaing untuk mendapatkan klien (perusahaan publik) dengan cara berusaha memberikan jasa audit sebaik mungkin. Perusahaan selain meminta jasa audit kepada KAP untuk audit yang pertama dapat juga meminta jasa audit untuk kondisi penggantian audit (Boynton dan Kell, 2006). Penelitian ini bertujuan mendeskripsikan pengaruh pergantian manajemen, kesulitan keuangan, fee audit, opini akuntan dan ukuran kap terhadap audit changes.

Secara umum auditing adalah suatu proses sistematik yang memperoleh dan mengevaluasi bukti-bukti secara objektif mengenai pernyataan-pernyataan tentang kegiatan dan kejadian ekonomi, dengan tujuan untuk menetapkan tingkat kesesuaian antara pernyataanpernyataan tersebut dengan kriteria yang telah ditetapkan, serta penyampaian. hasil-hasilnya kepada pemakai yang berkepentingan (Mulyadi, 2002).

Audit dilakukan auditor adalah salah satu fungsi untuk menentukan apakah laporan keuangan yang disusun manajemen telah memenuhi kriteria yang telah disepakati bersama 
atau telah memenuhi ketentuan-ketentuan yang telah ditetapakan oleh Prinsip Akuntansi Berterima Umum (PABU). Alasan utama adanya profesi auditor adalah untuk melakukan fungsi pengesahan atau menyakinkan akan kewajaran laporan keuangan. Auditor memberikan sumbangan berupa kepercayaan terhadap laporan keuangan untuk dapat digunakan sebagai dasar pengambilan keputusan oleh pihak-pihak pemakai laporan keuangan. Dengan kata lain laporan keuangan telah diaudit oleh auditor independen lebih dapat dipercaya dibandingkan dengan tidak diaudit. Dalam mengaudit, auditor selalu berpedoman pada standar auditing. Standar auditing terdiri dari 3 (tiga) bagian, yaitu standar umum, standar pekerjaan lapangan dan standar pelaporan. Setelah melakukan pemeriksaan auditor memberikan pendapat atas kewajaran laporan keuangan yang diperiksa.

Auditor Changes merupakan perpindahan auditor (KAP) yang dilakukan oleh perusahaan klien. Hal ini disebabkan oleh beberapa faktor, yaitu merjer atau dua perusahaan yang kantor akuntan publiknya berbeda, ketidakpuasan terhadap kantor akuntan publik yang dahulu, dan merjer antar kantor akuntan publik (Halim, 2008).

Mardiyah (2002) menyatakan dua faktor yang mempengaruhi perusahaan berpindah KAP adalah faktor klien (Clien-Related Factor), yaitu kesulitan keuangan, manajemen yang gagal, perubahan ownership, Initial Public Offering (IPO) dan faktor auditor (Auditor Related Factor), yaitu fee audit dan kualitas audit.

Pergantian auditor secara wajib dengan secara sukarela biasanya dibedakan atas dasar pihak mana yang menjadi fokus perhatian dari isu tersebut. Jika pergantian auditor terjadi secara sukarela, maka perhatian utama adalah pada sisi klien. Sebaliknya, jika pergantian secara wajib, perhatian utama beralih kepada auditor (Febrianto, 2009).

Penelitian yang pernah dilakukan oleh Kawijaya dan Juniarti (2002) tentang perpindahan auditor pada perusahaan-perusahaan di Surabaya dan Sidoarjo yang pernah di audit oleh kantor akuntan publik, menunjukkan bahwa tidak ada bukti signifikan bahwa qualified audit opinion, merger, management changes, expansion merupakan variabel yang memprediksi perpindahan auditor. Penelitian lain pernah pula dilakukan oleh Mardiyah (2002) untuk mengetahui pengaruh perubahan kontrak, keefektifan auditor, reputasi klien, biaya audit, faktor klien, dan faktor auditor terhadap auditor changes dengan analisis regresi dan model RPA (Recursive Partitioning Algorithm). Aryanti (2003) melakukan penelitian dari sudut pandang opini dengan hasil bahwa faktor yang mempengaruhi perpindahan KAP adalah kesulitan keuangan perusahaan, karakteristik KAP, dan permintaan kreditur bank.

Studi Hudaib dan Cooke (2005) meneliti efek interaktif perubahan Managing Director/ Chief Excutive Officer (MD) dan kesulitan bersama-sama dengan lima variabel control (jenis perusahaan audit, fee audit, gearing, waktu, dan ukuran perusahaan) pada opini audit dan auditor switching. Hudaib dan Cooke (2005) menemukan bahwa perusahaan yang tertekan secara financial dan mengubah MD paling mungkin untuk menerima laporan audit yang qualified, ceteris paribus. Selain itu Hudaib dan Cooke (2005) menemukan bukti dari ancaman keakraban dan intimidasi dan bahwa probabilitas switching meningkat dengan tingkat keparahan opini qualified.

Penelitian Nasser et al. (2006) menelaah perilaku audit tenure dan audit switching dalam lingkungan audit Malaysia untuk periode 1990-2000. Penelitian ini memberikan bukti tentang hubungan antara switching dan dua variabel, yaitu ukuran klien dan financial distress. Sementara, Damayanti dan Sudarma (2007) melakukan penelitian bahwa faktor-faktor yang mempengaruhi perusahaan berpindah KAP adalah fee audit dan ukuran KAP. Kedua variable tersebut adalah faktor yang sangat erat kaitannya dengan dengan perpindahan kantor akuntan publik. 
UNISIA, Vol. XXXIII No. 75 Juli 2011

\section{PENGARUH PERGANTIAN MANAJEMEN TERHADAP AUDIT CHANGES}

Pergantian manajemen perusahaan dapat diikuti oleh perubahan kebijakan dalam bidang Akuntansi, keuangan, dan pemilihan KAP. Perusahaan akan mencari KAP yang selaras dengan kebijakan dan pelaporan Akuntansinya (Nagy, 2005). Manajemen memerlukan auditor yang lebih berkualitas dan mampu memenuhi tuntutan pertumbuhan perusahaan yang cepat. Jika hal ini tidak terpenuhi, kemungkinan besar perusahaan akan mengganti auditornya (Joher et al, 2000); sehingga hipotesis penelitian ini antara lain:

H1: Pergantian manajemen berpengaruh positif terhadap audit changes (Pengaruh Kesulitan Keuangan Perusahaan Terhadap Audit changes)

Ada dorongan yang kuat untuk berpindah auditor pada perusahaan yang terancam bangkrut untuk berpindah KAP (Schwartz dan Menon, 1985). Selain itu, Schwartz dan Soo (1995) menyatakan bahwa perusahaan yang bangkrut lebih sering berpindah auditor dari pada perusaahaan yang tidak bangkrut. Kesulitan keuangan perusahaan ditunjukkan oleh Zmijewski (1984) dalam kadir (1994) salah satunya adalah dengan menggunakan solvabilitas. Solvabilitas ditunjukkan dengan membandingkan total kewajiban dengan total aktiva. Jadi:

H2: Kesulitan keuangan berpengaruh positif terhadap audit changes (Pengaruh Fee audit Terhadap Audit Changes)

Krishnan dan Ye (2005) menyatakan bahwa penunjukan KAP oleh perusahaan, yang diwakili oleh pemegang saham, berhubungan dengan total fees yang mereka bayarkan. Dorongan untuk berpindah KAP dapat disebabkan oleh fee audit yang relatif lebih tinggi yang ditawarkan oleh suatu KAP pada perusahaan sehingga tidak ada kesepakatan antara perusahaan dengan KAP tentang besarnya fee audit dan dapat mendorong perusahaan untuk berpindah kepada KAP yang lain (Schwartz dan Menon, (1985)).

H3: Fee audit berpengaruh positif terhadap audit changes (Pengaruh OpiniAkuntan Terhadap Audit Changes)

Jika auditor tidak dapat memberikan opini wajar tanpa pengecualian (tidak sesuai dengan harapan perusahaan), perusahaan akan bepindah KAP yang mungkin dapat memberikan opini sesuai dengan yang diharapkan perusahaan (Tandirerung, 2006). Manajemen akan memberhentikan auditornya sebagai suatu bentuk hukuman atas opini yang tidak diharapkan perusahaan atas laporan keuangannya dan berharap untuk mendapatkan auditor yang lebih mudah diatur/ more pliable (Carcello dan Neal, 2003). Perusahaan cenderung berpindah KAP setelah menerima qualified opinion atas laporan keuangan. Jadi:

H4: Opini akuntan berpengaruh positif terhadap audit changes (Pengaruh Ukuran KAP Terhadap Audit Changes)

Perusahaan akan mencari KAP yang kredibilitasnya tinggi untuk meningkatkan kredibilitas laporan keuangan dimata pemakai laporan keuangan itu (Halim, 2008). Expertise KAP merupakan salah satu atribut dalam servis KAP besar (Mardiyah, 2002). Adanya faktor expertise itu akan menentukan perubahan auditor oleh perusahaan sehingga perusahaan lebih memilih KAP besar. Eichenseher dan Shields dalam Kartika (2006) mengemukakan fenomena bahwa persepsi expensive/mahalnya kantor akuntan akan menentukan kesuksesan klien. Jadi:

H5: Ukuran KAP berpengaruh positif terhadap audit changes (Kerangka Pemikiran

Berikut ini adalah kerangka pemikiran dalam penelitian 


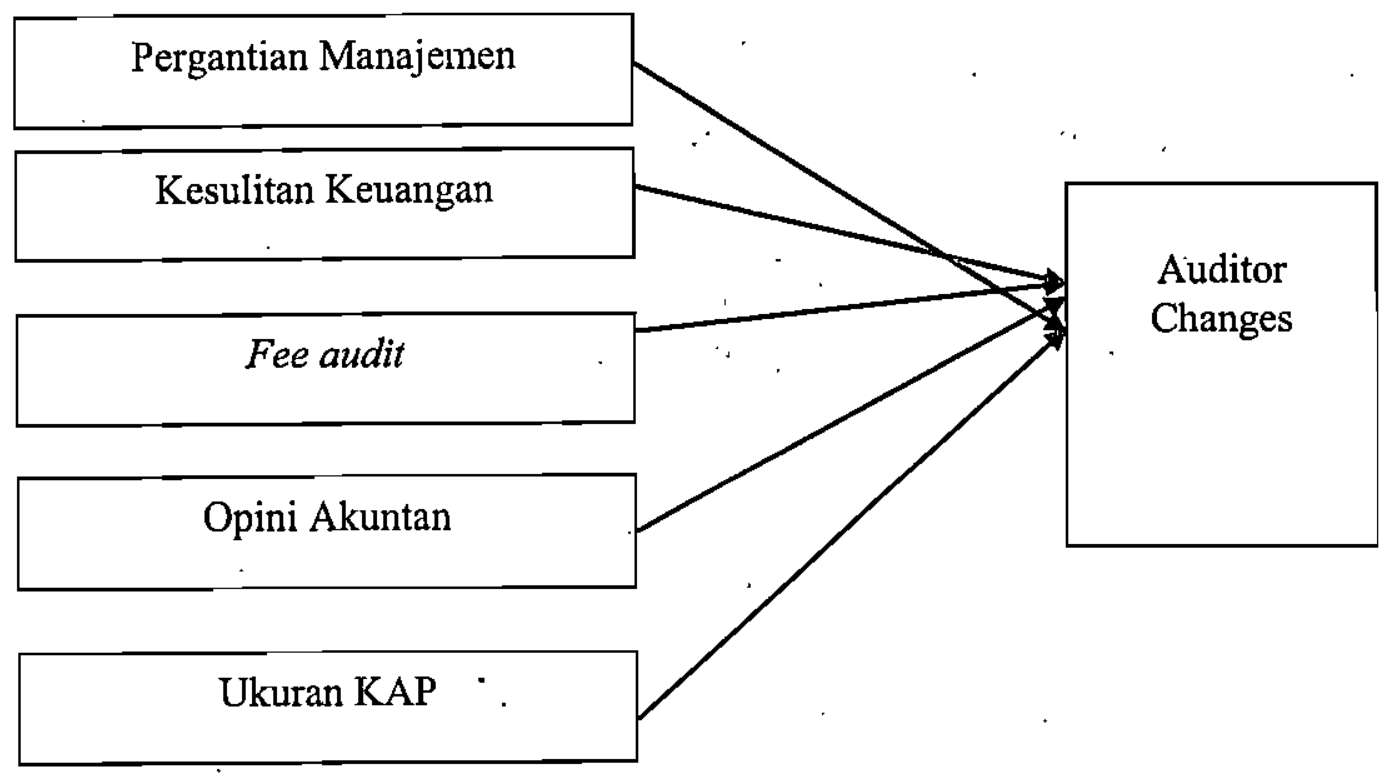

Gambar 1. Kerangka Pemikiran

Populasi dalam penelitian ini adalah perusahaan manufaktur yang merupakan emiten di Bursa Efek Indonesia (BEI) selama periode 2007-2010. Metode pengumpulan sampel (sampling method) yang digunakan adalah purposive sampling. Adapun kriteria sampel sebagai berikut: Perusahaan yang datanya lengkap dan perusahaan yang bukan bersifat mandatory dari pemerintah (KMK 423/KMK.06/2008).

Variabel dependen penelitian ini adalah auditor changes, merupakan perpindahan (KAP) yang dilakukan oleh perusahaan klien. Variabel auditor changes menggunakan variabel dummy. Jika perusahaan klien mengganti KAP, maka diberi nilai 1. Maksud mengganti KAP adalah jika mengganti KAP yang bukan karena mandatory. Untuk pergantian KAP dilihat data dari tahun $2003-2010$. Untuk mengetahui pada tahun 2007 melakukan perpindahan KAP atau tidak dan perpindahan tersebut bersifat mandatory atau tidak, sedangkan perusahaan tidak mengganti KAP, maka diberi nilai 0 (Nasser et. al., 2006).

Sedangkan varaibel independen penelitian terdiri atas: (1) Pergantian Manajemen, (2) Kesulitan Keungan Perusahaan, (3) Fee audit, (4) Opini Akuntan, dan (5) Ukuran KAP. Pergantian manajemen merupakan pergantian direksi perusahaan yang terutama disebabkan oleh keputusan rapat umum pemegang saham dan direksi berhenti karena kemauan sendiri. Variabel pergantian manajemen menggunakan variabel dummy. Jika terdapat pergantian direksi dalam perusahan maka diberikan nilai 1. Jika tidak terdapat pergantian direksi dalam perusahaan maka diberikan nilai 0 (Damayanti dan Sudarma, 2007).

Fee audit merupakan besarnya atau jumlah fee yang ditawarkan oleh suatu KAP kepada perusahaan yang berkaitan dengan pekerjaan audit dengan melihat perpindahan kelas KAP dari Non Big 4 ke Big 4 atau sebaliknya. Tidak melakukan perpindahan kelas auditor artinya sudah setuju dengan fee audit (Damayanti dan Sudarma). Dorongan untuk berpindah KAP dapat disebabkan oleh fee audit yang relatif lebih tinggi yang ditawarkan oleh suatu KAP pada perusahaan sehingga tidak ada kesepakatan antara perusahaan dengan KAP tentang besarnya fee audit dan dapat mendorong perusahaan untuk berpindah kepada KAP yang lain (Schwartz dan Menon, (1985). Variabel fee audit menggunakn variabel dummy. Jika klien melakukan perpindahan KAP dari Big Four maka diberikan nilai 1. Sedangkan jika klien tidak melakukan perpindahan KAP dari Big Four, maka diberikan nilai 0 (Damayanti dan Sudarma).

Opini audit merupakan pendapat yang diberikan oleh auditor dalam menilai kewajaran perjanjian suatu laporan keuangan perusahaan yang di auditnya. Variabel opini akuntan 
menggunakan variabel dummy. Jika perusahaan klien menerima opini selain wajar tanpa pengecualian (unqualified) maka diberikan nilai 1. Sedangkan jika perusahaan klien menerima opini wajar tanpa pengecualian (unqualified) maka diberikan nilai 0 (Damayanti dan Sudarma, 2007).

Ukuran KAP dalam penelitian ini merupakan besar kecilnya KAP yang dibedakan dalam dua kelompok. Yaitu KAP yang berafiliasi dengan Big 4 dan KAP yang tidak berafiliasi dengan Big 4. Variabel ukuran KAP menggunakan variabel dummy. Jika perusahaan diaudit oleh KAP Big 4 maka diberikan nilai 1. Sedangkan jika sebuah perusahaan diaudit oleh KAP Non Big 4, maka diberikan nilai 0 (Nasser et.al., 2006).

Alat analisis yang digunakan dalam penelitian ini adalah analisis regresi logistik (logistic regression). Alasan penggunaan alat analisis regresi logistik adalah karena variabel dependen bersifat dikotomi (melakukan auditor changes dan tidak melakukan auditor changes). Asumsi normal distribution tidak dapat dipenuhi karena variabel bebas merupakan campuran antara variabel kontinyu (metriks) dan kategorial (non-metrik). Dalam hal ini dapat dianalisis dengan regresi logistik (logistic regression) karena tidak perlu asumsi normalitas data pada variabel bebasnya.

Untuk menguji hipotesis penelitian, estimasi parameter menggunakan Maximum Likehood Estimation (MLE).

$$
\begin{aligned}
& \mathrm{Ho}=\mathrm{b} 1=b 2=b 3=\ldots=b i=0 \\
& \mathrm{Ho} \neq \mathrm{b} 1 \neq b 2 \neq b 3 \neq \ldots \neq b i \neq 0
\end{aligned}
$$

Hipotesis nol menyatakan bahwa variabel independen $(x)$ tidak mempunyai pengaruh terhadap variabel respon yang diperhatikan (dalam populasi). Pengujian terhadap hipotesis dilakukan dengan menggunakan $\alpha=5 \%$. Kaidah pengambilan keputusan adalah:

1. Jika nilai probabilitas (sig.) $<\alpha=5 \%$ maka hipotesis alternatif didukung.

2. Jika nilai probabilitas (sig.) $>\alpha=5 \%$ maka hipotesis alternatif tidak dididukung.

Adapun model regresi dalan penelitian ini adalah sebagai berikut:

$\begin{array}{ll}\text { CHANGES }_{\mathrm{Y}}= & \text { bo }+\mathrm{b}_{1} \mathrm{CEO}+\mathrm{b}_{2} \mathrm{DER}+\mathrm{b}_{3} \mathrm{FEE}+\mathrm{b}_{4} \mathrm{OPINI}+\mathrm{b}_{5} \mathrm{KAP}+\mathrm{e} \\ \text { CHANGES } & : \text { Auditor Changes } \\ \text { bo } & : \text { Kostanta } \\ \mathrm{b}_{1}-\mathrm{b}_{8} & : \text { Koefisien regresi } \\ \text { CEO } & : \text { Pergantian manajemen } \\ \text { DER } & : \text { Kesulitan keuangan perusahaan } \\ \text { FEE } & : \text { Fee audit } \\ \text { OPINI } & : \text { Opini akuntan } \\ \text { KAP } & : \text { Ukuran KAP } \\ \mathrm{e} & : \text { Residual }\end{array}$




\section{HASIL PENELITIAN} berikut :

Rincian jumlah perusahaan sampel yang digunakan dalam penelitian ini adalah sebagai

\section{Tabel 1}

Perincian Perhitungan Sampel

\begin{tabular}{|c|l|c|}
\hline No. & \multicolumn{1}{|c|}{ Keterangan } & Jumlah perusahaan \\
\hline 1. & Perusahaan yang terdaftar di BEI dari tahun 2007 -2010 & 442 \\
\hline 2. & $\begin{array}{l}\text { Perusahaan selain sektor manufaktur yang terdaftar di } \\
\text { BEI dari tahun 2007 - 2010 }\end{array}$ & $(301)$ \\
\hline 3. & Perusahaan yang datanya tidak lengkap & $(12)$ \\
\hline 4. & $\begin{array}{l}\text { Perusahaan yang bersifat mandatory dari pemerintah } \\
\text { (KMK 423/KMK 06/2008) }\end{array}$ & 125 \\
\hline & $\begin{array}{l}\text { Jumlah sampel perusahaan yang digunakan dalam } \\
\text { penelitian }\end{array}$ & 14 \\
\hline
\end{tabular}

Berdasarkan kriteria sampel yang telah ditetapkan maka diperoleh sebanyak 125 perusahaan sektor perusahaan manufaktur yang digunakan sebagai sampel dalam penelitian ini.

Setelah diuji dengan menggunakan overall model fit, negelkerke R-Square, Hosmer Lemesgow's Goodness of Fit Test, uji multikolinieritas dan matriks klasifikasi, maka diperoleh regresi logistik yang terbentuk. Adapun hasil uji regresi logistik adalah sebagai berikut:

Tabel 2

Hasil Uji Koefisien Regresi Logistik

\begin{tabular}{|l|r|r|r|r|r|r|}
\hline Keterangan & \multicolumn{1}{|c|}{ B } & \multicolumn{1}{c|}{ S.E } & \multicolumn{1}{c|}{ Wald } & \multicolumn{1}{c|}{ df } & \multicolumn{1}{c|}{ Sig } & \multicolumn{1}{c|}{ Exp(B) } \\
\hline CEO &, 036 &, 256 &, 020 & 1 &, 887 & 1,037 \\
\hline DER &, 000 &, 003 &, 002 & 1 &, 966 & 1,000 \\
\hline Fee audit & 2,853 & 1,156 & 6,090 & 1 &, 014 & 17,340 \\
\hline OA &,- 390 &, 524 &, 555 & 1 &, 456 &, 677 \\
\hline UK_KAP &, 820 &, 309 & 6,032 & 1 &, 008 & 2,271 \\
\hline Constant & $-1,674$ &, 163 & 105,838 & 1 &, 000 &, 187 \\
\hline
\end{tabular}

Sumber: hasil olah data tahun 2012

Berdasarkan Tabel 2, maka dapat disusun hasil persamaan regresi sebagai berikut : CHANGES $=-1,674+0,036$ CEO $+0,000$ DER $+2,853$ FEE $-0,3900 \mathrm{~A}+0,820 \mathrm{KAP}$

\section{Pengaruh Pergantian Manajemen Terhadap Audit Changes}

Variabel ini menjelaskan pergantian direksi perusahaan yang terutama disebabkan oleh keputusan rapat umum pemegang saham dan direksi berhenti karena kemauan sendiri, variabel ini memiliki nilal koefisien regresi positif sebesar 0,036 dengan tingkat signifikansi sebesar 0,887 yang lebih besar dari 0,05. Hal ini berarti pergantian manajemen tidak berpengaruh terhadap pergantian KAP, sehingga hipotesis pertama yang menyatakan 
pergantian manajemen berpengaruh positif terhadap perusahaan yang berpindah KAP tidak terbukti.

Penelitian ini gagal membuktikan adanya pengaruh pergantian manajemen (CEO) terhadap auditor changes. Hasil penelitian ini mendukung hasil penelitian Damayanti dan Sudarma (2007), tetapi bertentangan dengan hasil penelitian Mardiyah (2002). Hasil pengujian menunjukkan bahwa pergantian manajemen tidak selalu diikuti dengan pergantian kebijakan perusahaan dalam menggunakan jasa suatu KAP. Hal tersebut menunjukkan bahwa kebijakan dan pelaporan akuntansi KAP lama tetap dapat diselaraskan dengan kebijakan manajemen baru dengan cara melakukan negosiasi ulang antara kedua pihak. Adanya fenomena seperti ini erat kaitannya dengan keadaan perusahaan publik di Indonesia yang mayoritas dikuasai dan dijalankan bersama oleh orang-orang dalam satu keluarga.

\section{Pengaruh Kesulitan Keuangan Perusahaan Terhadap Audit Changes}

Variabel ini menginformasikan kondisi perusahaan akan informasi kebangkrutan. Variabel ini memiliki nilai koefisien regresi sebesar 0,000 dengan tingkat signifikansi sebesar 0,966 yang lebih besar dari 0,05 . Hal ini berarti kesulitan keuangan perusahaan tidak berpengaruh terhadap perpindahan KAP. Penelitian ini gagal membuktikan bahwa kesulitan keuangan perusahaan berpengaruh terhadap auditor changes. Hasil penelitian ini mendukung hasil penelitian Kartika (2006), dan Damayanti dan Sudarma (2007).

Kondisi perusahaan klien terancam bangkrut cenderung meningkatkan evaluasi subjektivitas dan kehati-hatian auditor. Dalam kondisi seperti ini suatu perusahaan akan cenderung melakukan pergantian KAP. Auditor changes juga disebabkan karena perusahaan sudah tidak lagi memiliki kemampuan untuk membayar biaya audit yang dibebankan oleh KAP yang diakibatkan penurunan kemampuan keuangan perusahaan.

Hasil penelitian ini menunjukkan bahwa kesulitan keuangan justru tidak menjadi faktor penyebab perusahaan untuk melakukan perpindahan KAP. Hal tersebut disebabkan karena sebagian besar perusahaan yang dijadikan sampel menggunakan jasa KAP Non Big Four, dengan demikian perpindahan ke penggunaan jasa KAP Big Four justru akan semakin menyulitkan kondisi keuangan perusahaan karena kenaikan jasa audit. Selain itu auditee yang insolvent dan mengalami posisi keuangan yang tidak sehat lebih mungkin untuk mengikat auditornya untuk menjaga kepercayaan pemegang saham, kreditor serta risiko litigasi.

\section{Pengaruh Fee audit Terhadap Audit Changes}

Variabel ini memberikan gambaran mengenai besarnya atau jumlah fee yang ditawarkan oleh suatu KAP kepada perusahaan yang berkaitan dengan pekerjan audit dengan melihat perpindahan kelas KAP dari Non Big 4 ke Big 4 atau sebaliknya. Tidak melakukan perpindahan kelas KAP artinya sudah setuju dengan fee audit. Variabel memiliki nilai koefisien regresi positif sebesar 2,853 dengan tingkat signifikansi sebesar 0,014 yang lebih kecil dari 0,05 . Hal ini berarti fee audit berpengaruh terhadap perpindahan KAP.

Penelitian ini berhasil membuktikan bahwa fee audit berpengaruh terhadap auditor changes. Hasil penelitian ini mendukung hasil penelitian Damayanti dan Sudarma (2007). Perusahaan cenderung memilih fee audit yang lebih rendah, karena kualitas jasa yang diberikan oleh setiap KAP adalah sama. Setiap KAP dalam melaksanakan tugasnya selalu berpedoman pada Sistem Pengendalian Mutu (SPM). Sistem Pengendalian Mutu 
setiap KAP selalu direview oleh Departemen Keuangan. Review yang dilaksanakan oleh Departemen Keuangan dilakukan baik secara mendadak maupun secara reguler.

\section{Pengaruh Opini Akuntan Terhadap Audit Changes}

Opini audit merupakan pendapat yang diberikan oleh auditor dalam menilai kewajaran perjanjian suatu laporan keuangan perusahaan yang di auditnya. Variabel ini memiliki nilai koefisien regresi negatif sebesar 0,390 dengan tingkat signifikansi sebesar 0,456 yang lebih besar dari 0,05 . Hal ini berarti opini akuntan tidak berpengaruh terhadap perpindahan KAP

Penelitian ini gagal membuktikan adanya pengaruh opini audit terhadap auditor changes. Hasil penelitian ini mendukung hasil penelitian Damayanti dan Sudarma (2007). Hasil pengujian yang gagal menemukan adanya pengaruh signifikan diduga disebabkan karena pada umumnya perusahaan sampel telah mendapatkan opini unqualified. Selain itu, jika perusahaan menggunakan KAP Big Four, hal tersebut menyebabkan perusahaan tidak terlalu memiliki keleluasaan untuk melakukan auditor changes apabila penugasan KAP oleh manajemen dianggap tidak lagi sesuai. Pergantian kelas KAP dari Big Four dikhawatirkan dapat menyebabkan adanya sentimen negatif dari pelaku pasar terhadap kualitas pelaporan keuangan dari perusahaan. Sebaliknya, pergantian kelas KAP ke Big Four dikhawatirkan dapat menyebabkan tidak adanya kemungkinan untuk mendapatkan opini unqualified karena pertimbangan kualitas audit yang lebih baik.

\section{Pengaruh Ukuran KAP Terhadap Audit Changes}

Ukuran KAP dalam penelitian ini merupakan besar kecilnya KAP yang dibedakan dalam dua kelompok. Yaitu KAP yang berafiliasi dengan Big Four dan KAP yang tidak berafiliasi dengan $\mathrm{Big} 4$. Variabel ini memiliki nilai koefisien regresi positif sebesar 0,820 dengan tingkat signifikansi sebesar 0,008 yang lebih kecil dari 0,05 . Hal ini berarti ukuran KAP berpengaruh terhadap perpindahan KAP

Hasil penelitian ini mendukung hasil penelitian sebelumnya yang dilakukan oleh Mardiyah (2002), Kartika (2006), dan Damayanti dan Sudarma (2007), tetapi tidak mendukung penelitian Nasser et al. (2006).

Pada saat ini KAP Big Four dianggap memiliki kualitas yang lebih tinggi apabila dibandingkan dengan KAP Non Big Four. Hal ini dikarenakan anggapan bahwa kredibilitas perusahaan semata-mata ditentukan oleh pemakaian jasa KAP Big Four. Perusahaan akan mencari KAP yang kredibilitasnya tingi untuk meningkatkan kredibilitas laporan keuangan di mata pemakai laporan keuangan. Expertise KAP merupakan salah satu atribut dalam servis KAP besar. Adanya faktor expertise akan menentukan perubahan KAP oleh perusahaan, sehingga perusahaan lebih memilih KAP besar. Fenomena bahwa persepsi expensive/mahalnya KAP akan menentukan kesuksesan klien.

\section{KESIMPULAN}

Berdasarkan hasil analisis pengaruh dari variabel-variabel pergantian manajemen, fee audit, kesulitan keuangan perusahaan, kesulitan keuangan, fee audit, opini akuntan dan ukuran KAP terhadap audit changes pada perusahaan manufaktur yang terdaftar di Bursa Efek Indonesia dapat diambil kesimpulan bahwa terdapat pengaruh positif yang signifikan dari fee audit dan ukuran KAP terhadap audit changes pada perusahaan di Indonesia. Sedangkan variabel pergantian manajemen, kesulitan keuangan dan opini akuntan tidak mempunyai pengaruh terhadap perusahaan manufaktur di Indonesia untuk audit changes. 
UNISIA, Vol. XXXIII No. 75 Juli 2011

Keterbatasan dalam penelitian ini adalah: (1) Sampel yang digunakan adalah perusahaan manufaktur yang terdafar di BEl pada tahun $2007-2010$, dan (2) variabel yang digunakan hanya pergantian manajemen, kesulitan keuangan, fee audit, opini audit dan uuran KAP. Dari keterbatasan-keterbatasan tersebut, maka untuk penelitian yang akan datang disarankan: (1) sampel yang digunakan adalah semua perusahaan yang go publik; dan (2) variabel yang digunakan sebaiknya ditambah dengan variabel lain, misalnya opini going concern, ukuran klien, tingkat pertumbuhan klien, profitabilitas dan lain-lain.

\section{DAFTAR PUSTAKA}

Anindito, Rahman Soeryo dan Fitriany (2009) "Faktor-faktor yang Mempengaruhi Pergaintian Akuntan PublikPada Perusahaan Manufaktur yang Terdaftar di Bursa Efek Indonesia", Proposal Doktoral Universitas Indonesia.

Aryanti , A.D. (2003) "Analisis Faktor-Faktor Yang Mempenaruhi Keputusan Klien Melakukan Pergantian Kantor Akuntan Publik (Survei beberapa KAP di Surabaya dan Malancl)", Skripsi Fakultas Ekonomi Universitas Brawijaya, Malang.

Bursa Efek Indonesia. n.d. Indonesia Capital Market Directory 2003-2010. Jakarta: Bursa Efek Indonesia.

Damayanti, S. dan M. Sudarma (2007) "Faktor-Faktor yang Mempengaruhi Perusahaan Berpindah Kantor Akuntan Publik". Makalah Simposium Nasional Akuntansi 11. Pontianak.

Febrianto, R. (2009) “Pergantian Auditor dan Kantor Akuntan Publik". (http://rfebrianto.blogspot. com/2009/05/pergantian-auditor-dan-kantor-akuntan.html, diakses 25 November 2009)

Ghozali, I. (2005) Aplikasi Analisis Mulitivariate dengan Program SPSS. Semarang: Badan Penerbit Universitas Diponegoro.

Halim, Abdul (2008) Auditing. Edisi 4. Yogyakarta: UPP STIM YKPN.

Hudaib, M. dan T.E. Cooke (2005) "The Impact of Managing Director Changes and Financial Distress on Audit Qualification and Auditor Switching". Journal of Business Finance \& Accounting, Vol. 32. No. 9/10pp: 1703-1709.

http://antoagus.wordpress.com/2010/07/29/Pergantian-manajemen-kesulitan-keuanganperusahaan-ukuran-KAP-opini-akuntan-reputasi-perusahaan-terhadap-perpindahanKAP

Kawijaya, N. dan Juaniarti (2002) "Faktor-faktor Yang Mendorong Perpindahan Auditor (Auditor Switch) Pada Perusahaan-perusahaan di Surabaya dan Sidoarjo". Jurnal Akuntansi \& Keuangan. Vol. 4, No. 2, Nopember 2002: 93-105.

Kell, Walter G. dan William C. Boynton (2006) Modern Auditing. Edisi 8. New York: John Willey and Sons Inc.

Lubis, F. (2000) "Hubungan DuaArah (Simultaneous) antara Pendapat Audit dengan Pergantian Akuntan". Jurnal Bisnis dan Akuntansi, Vol. 2, No. 2, pp. 171-181. 
Pengaruh Pergantian Manajemen ... (Reni Yendrawati)

Mardiyah, A.A. (2002) "Pengarüh Perubahan Kontrak, Keefektifan Auditọr, Rejūtasi klien, Biaya Audit, Faktor Klien dan Faktor Auditor Terhadap Auditor Changes: Sebuah Pendekatan Dengan Model Kontijensi RPA". Akalah Simposium Nasional Ákuntansi V.'Semarang.

Mulyadi (2001) Auditing. Edisi ke-6 Jakarta: PT Salemba Empat.

Mutia, Ratna dan Choirul (2010) "Pengaruh Tekanan Waktu dan Tindakan Supervisi Terhadap Penghentian Prematur Atas Prosedur Audit". Simposium Nasional Akuntansi XIII. Purwokerto.

Santoso, Singgih (2003) Mengatasi Berbagai Masalah Statistik dengan SPSS. Jakarta: PT Elex Media Komputindo.

Sinason, D.H, Jones dan S.W. Shelton (2001) "An Investigation of Auditor and Client Tenure". Mid-American Journal of Business, Vol: 16, No. 2, pp. 31-40.

Suparlan, Wuryan Andayani (2010) "Analisis Empiris Pergantian Akuntan Publik Setelah Ada Kewajiban Rotasi Audit". Makalah Simposium Nasional Akuntansi .XIII. Purwokerto.

Wijayanti (2010) 'Faktor-faktor yang Mempengaruhi Pergantian KAP .Pada Perusahàan Manuffaktur". Makalah Simposium Nasional Akuntansi XIII. Purwokerto. 